International Journal of Legal Information 49.2, 2021, pp. 140-146. (C) The Author(s) 2021. Published by International Association of Law Libraries

doi:10.1017/jli.2021.16

\title{
INTERNATIONAL CALENDAR
}

2021

Due to the ongoing COVID-19 Pandemic, some 2021 conferences are being offered in an online or hybrid format.

\section{ALLA Conference (Australian Law Librarians' Association)}

"Past, Present, Future." Keynote speakers include Justice Stephen Gageler of the Australia High Court and Chief Justice Helen Murrell of the Australian Capital Territory Supreme Court. Programs include Legal Education-How UK changes Compare with Australia; A New Law Research Guide-Uniting Student and Expert Voices to Improve Online Learning Design; and Teaching Legal Research-Using Past Practice and Present Confusion to Inform Future Learning.

September 22-24, 2021

Canberra, ACT, Australia

https://allaconference.com.au/

\section{$39^{\text {th }}$ Annual Course of the International Association of Law Libraries (IALL)}

"The Triptych: National, European and International Law, the French Way." Programs include Introduction to French Private Law (Introduction au droit privé français); The Main Principles of French Public Law: A Comparative Reflection (Les grands principes de la culture juridique en droit public français: une réflexion comparée); and The French Legal Concept of Laïcité (La laïcité en droit français).

October 4-7, 2021

Virtual conference presented by Université Toulouse Capitole, Toulouse, France

http://iall.org/conf2021/

\section{AoIR 2021 (Association of Internet Researchers)}

The conference theme is "Independence." AoIR 2021 asks participants to consider and critique the relationship between "independence" and the internet and how that plays out in countries around the world and transnationally.

October 13-16, 2021

- nline

https://aoir.org/aoir2021cfp/

\section{$69^{\text {th }}$ Research Conference, Japan Society of Library and Information Science}

"Digital Archives and Libraries." The symposium will share information on the construction and practice of digital archives, paying particular attention to their relationship with libraries, and will discuss research issues in areas such as library and information science.

October 16-17, 2021

Kumamoto Gakuen University, Kumamoto City, Japan

https://jslis.jp/events/annual-conference/

\section{ICA Congress (International Council on Archives)}

"Empowering Knowledge Societies." The archival, records, and data landscape in the 21 st century is changing public expectations, how we do our work, what constitutes credible evidence and how we protect our 
holdings. It is time for our profession to discuss, reflect, and challenge existing practices to explore and expand the critical role played by archives and information professionals in the 21 st-century knowledge societies.

October 19-22, 2021

Abu Dhabi, UAE

https://www.ica.org/en/ica-2020-abu-dhabi-congress

\section{IBA Global Showcase (International Bar Association)}

Through a series of high-profile expert sessions, some of the biggest issues and challenges facing the global legal profession will be discussed. The IBA Global Showcase will highlight the diverse work and achievements of the IBA's membership in many key areas of policy and practice. There will also be sessions specifically designed for key groupings within the membership.

October 25-29, 2021

Online

https://www.ibanet.org/conference-details/CONF2013

\section{Internet Librarian 2021}

"Call to Action \& Innovation in Library Technology \& Communities." The $25^{\text {th }}$ Internet Librarian highlights some of the exciting changes that will likely become standard in the future, those that were great experiments from which we learned much, as well as creative new insights and plans for the future. Plans which include working with their communities in rebuilding and recovering from the economic and social issues arising from recent upheavals.

October 26-28, 2021

Monterey, CA, USA

http://internet-librarian.infotoday.com/2020/default.aspx

\section{Charleston Library Conference}

Hybrid event with both an in-person and virtual option.

November 1-5, 2021

Charleston, SC, USA

https://www.charleston-hub.com/the-charleston-conference/about-the-conference/future-conference-dates/

\section{LIANZA 2021 Conference}

"Thriving Together: E huri tō aroaro kit e rā, Tukuna tō ataarangi ki muri I a koe."

November 9-11, 2021

Museum of New Zealand, Te Papa Tongarewa, Wellington, NZ and Online

https://ianza.org.nz/events/lianza-2021-conference/

\section{ASIL Midyear Meeting (American Society of International Law)}

The Midyear Meeting encompasses several events, including leadership meetings of the Society's Executive Council and the Board of Editors of the American Journal of International Law; the Research Forum, which features cutting-edge international law scholarship by more than 70 authors; and the Practitioners' Forum.

November 11-13, 2021

University of Miami School of Law, Miami, FL, USA (Tentative)

https://www.asil.org/midyear-meeting

\section{$7^{\text {th }}$ International Conference of Asian Special Libraries}

Organized by the Special Library Association Asia Community. "Envisioning the Future of Library in the Post-Coronavirus Era." The 2021 conference will discuss all aspects of special libraries such as: the proposal of innovation to turn the crisis of COVID-19 into a leap of opportunity in the wake of the social changes 
caused by the pandemic, suggestion of new policies to prepare for a new future, and cases of successful outcomes in special libraries.

November 24-26, 2021

National Library Korea, Seoul, South Korea

https://connect.sla.org/asia/events/icoasl2021

\section{$\mathbf{2 3}^{\text {rd }}$ International Conference on Grey Literature}

"Digital Transformation of Grey Literature: Exploring Next Generation Grey." GL 2021 offers the many and diverse communities of practice in grey literature a unique opportunity to collaborate in addressing and defining the next phase in the digital transformation of grey literature.

December 6-7, 2021

Amsterdam, Netherlands

http://www.textrelease.com/2021 conference.html

2022

\section{AALS Annual Meeting (Association of American Law Schools)}

"Freedom, Equality, and the Common Good." As we emerge from the pandemic and begin to address the social, economic, and political turmoil left in its wake, it is the right time to explore these three concepts critical to our understanding of democracy and the rule of law.

January 5-9, 2022

New York, NY, USA

https://www.aals.org/events/

\section{LibLearnX: The Library Learning Experience (ALA)}

"Learn. Network. Celebrate." LibLearnX is a member-focused education experience designed to motivate, inspire, and engage discussions that will shape the future of libraries and their communities.

January 21-24, 2022

San Antonio, TX, USA

https://alaliblearnx.org/

\section{ABA Midyear Meeting (American Bar Association)}

February 9-14, 2022

Seattle, WA, USA

https://www.americanbar.org/groups/departments_offices/meetings_travel_dept/future-past-meetings/

\section{Computers in Libraries 2022}

March 28-31, 2022

Arlington, VA, USA

http://computersinlibraries.infotoday.com/2020/PastEvents.aspx

\section{ASIL 2022 Annual Meeting (American Society of International Law)}

"Personalizing International Law." The Annual Meeting will focus on how international law is experienced personally, including the interaction of individuals with international law in their daily lives and who is prioritized in the public and private application of international law. Thematic tracks include International Law Beyond the State, The Competing Values of International Law, and International Law in the Information Age.

April 6-9, 2022

Washington, DC, USA

https://www.asil.org/annualmeeting 
The Teaching Professor Conference

The Teaching Professor Conference is a three-day event focused on the latest research-based, classroomtested best practices to enhance knowledge and drive ever-better outcomes for students.

June 3-5, 2022

Atlanta, GA, USA

https://www.magnapubs.com/teaching-professor-conference/2022-teaching-professor-conference/

\section{ALA Annual Conference \& Exhibition (American Library Association)}

June 23-28, 2022

Washington, DC, USA

https://www.ala.org/conferencesevents/ala-upcoming-annual-conferences-liblearnx

AALL Annual Meeting (American Association of Law Libraries)

July 16-19, 2022

Denver, CO, USA

https://www.aallnet.org/conference/about/future-meetings/

\section{LWI Biennial Conference (Legal Writing Institute)}

July 20-23, 2022

Georgetown University Law Center, Washington, DC, USA

https://www.lwionline.org/conferences/2022-lwi-biennial-conference

\section{ABA Annual Meeting (American Bar Association)}

August 3-9, 2022

Chicago, IL, USA

https://www.americanbar.org/groups/departments_offices/meetings_travel_dept/future-past-meetings/

IFLA World Library and Information Congress

August 13-19, 2022

Dublin, Ireland

https://www.ifla.org/node/93335

86 $^{\text {th }}$ Annual Meeting of the Society of American Archivists

August 20-27, 2022

Boston, MA, USA

https://www2.archivists.org/am2022

$40^{\text {th }}$ Annual Course of the International Association of Law Libraries

October 9-12, 2022

Stanford Law School, Stanford, CA, USA

http://iall.org/annual-conference-2/

IBA Annual Conference (International Bar Association)

October 30-November 4, 2022

Miami Beach, FL, USA

https://www.ibanet.org/conference-details/conf927

\section{Charleston Library Conference}

October 31-November 4, 2022

Charleston, SC, USA 
https://www.charleston-hub.com/the-charleston-conference/about-the-conference/future-conference-dates/

2023

AALS Annual Meeting (Association of American Law Schools)

January 3-7, 2023

San Diego, CA, USA

https://www.aals.org/events/

LibLearnX: The Library Learning Experience (American Library Association)

January 27-31, 2023

New Orleans, LA, USA

http://www.ala.org/conferencesevents/ala-upcoming-annual-conferences-liblearnx

ABA Midyear Meeting (American Bar Association)

February 1-6, 2023

New Orleans, LA, USA

https://www.americanbar.org/groups/departments_offices/meetings_travel_dept/future-past-meetings/

ACRL Conference 2023 (Association of College \& Research Libraries)

March 15-18, 2023

Pittsburgh, PA, USA

http://www.ala.org/acrl/conferences

\section{ALA Annual Conference (American Library Association)}

June 22-27, 2023

Chicago, IL, USA

http://www.ala.org/conferencesevents/ala-upcoming-annual-conferences-liblearnx

AALL Annual Meeting (American Association of Law Libraries)

July 15-19, 2023

Boston, MA, USA

https://www.aallnet.org/conference/about/future-meetings/

Annual Meeting of the Society of American Archivists

July 22-29, 2023

Washington, DC, USA

https://www2.archivists.org/am2023

\footnotetext{
ABA Annual Meeting (American Bar Association)

August 2-8, 2023

Denver, CO, USA

https://www.americanbar.org/groups/departments_offices/meetings_travel_dept/future-past-meetings/

$4^{\text {st }}$ Annual Course, International Association of Law Libraries (IALL)

Presented by the ICRC Library, UN Library Geneva, and Graduate Institute Library

Fall 2023

Geneva, Switzerland

https://iall.org/annual-conference-2/
} 
IBA Annual Conference 2023 (International Bar Association)

October 29-November 3, 2023

Paris, France

https://www.ibanet.org/conferences

Charleston Library Conference

November 6-10, 2023

Charleston, SC, USA

https://www.charlestonlibraryconference.com/about/future-conference-dates/

2024

AALS Annual Meeting (Association of American Law Schools)

January 3-7, 2024

Washington, DC, USA

https://www.aals.org/events/

ALA Annual Conference (American Library Association)

June 27-July 2, 2024

San Diego, CA, USA

http://www.ala.org/conferencesevents/ala-upcoming-annual-conferences-liblearnx

\section{LWI Biennial Conference (Legal Writing Institute)}

July 17-20, 2024

Indiana University, Robert H. McKinney School of Law, Indianapolis, IN, USA

https://www.lwionline.org/conferences/2022-lwi-biennial-conference

AALL Annual Meeting (American Association of Law Libraries)

July 20-23, 2024

Chicago, IL, USA

https://www.aallnet.org/conference/about/future-meetings/

\section{ABA Annual Meeting (American Bar Association)}

July 31-August 6, 2024

Chicago, IL, USA

https://www.americanbar.org/groups/departments_offices/meetings_travel_dept/future-past-meetings/

88 $^{\text {th }}$ Annual Meeting of the Society of American Archivists

August 1, 2024

Chicago, IL, USA

https://www2.archivists.org/am2024

\section{Charleston Library Conference}

November 11-15, 2024

Charleston, SC, USA

https://www.charleston-hub.com/the-charleston-conference/about-the-conference/future-conference-dates/ 
ACRL Conference 2023 (Association of College \& Research Libraries)

April 2-5, 2025

Minneapolis, MN, USA

http://www.ala.org/acrl/conferences

\section{ALA Annual Conference (American Library Association)}

June 26-July 1, 2025

Philadelphia, PA, USA

http://www.ala.org/conferencesevents/ala-upcoming-annual-conferences-liblearnx

AALL Annual Meeting (American Association of Law Libraries)

July 19-22, 2025

Portland, OR, USA

https://www.aallnet.org/conference/about/future-meetings/

$89^{\text {th }}$ Annual Meeting of the Society of American Archivists

August 1, 2025

Anaheim, CA, USA

https://www2.archivists.org/am2025

\section{ABA Annual Meeting (American Bar Association)}

August 6-12, 2025

Toronto, ON, Canada

https://www.americanbar.org/groups/departments_offices/meetings_travel_dept/future-past-meetings/

\section{Charleston Library Conference}

November 3-7, 2025

Charleston, SC, USA

https:/www.charleston-hub.com/the-charleston-conference/about-the-conference/future-conference-dates/

ALA Annual Conference (American Library Association)

June 25-June 30, 2026

Chicago, IL, USA

http://www.ala.org/conferencesevents/ala-upcoming-annual-conferences-liblearnx

2027

ACRL Conference (Association of College \& Research Libraries)

April 7-10, 2027

Portland, OR, USA

https://www.ala.org/acrl/conferences

\section{ALA Annual Conference (American Library Association)}

June 24-29, 2027

New Orleans, LA, USA

https://www.ala.org/conferencesevents/ala-upcoming-annual-conferences-liblearnx 